\title{
AKTYWNOŚĆ FIZYCZNA SUBPOPULACJI W OKRESIE INWOLUCJI JAKO PRZECIWWAGA DLA HIPOKINEZY
}

\section{PHYSICAL ACTIVITY OF PEOPLE IN THE INVOLUTION PERIOD AS A COUNTERBALANCE FOR HYPOKINESIS}

\author{
Grzegorz Konieczny ${ }^{1}$, Renata Rasińska² \\ ${ }^{1}$ Zakład Pedagogiki \\ Akademia Wychowania Fizycznego im. Eugeniusza Piaseckiego w Poznaniu \\ ${ }^{2}$ Zakład Organizacji i Zarządzania w Opiece Zdrowotnej \\ Uniwersytet Medyczny im. Karola Marcinkowskiego w Poznaniu
}

DOI: http://dx.doi.org/10.20883/pielpol.2016.21

\begin{abstract}
STRESZCZENIE
Celem niniejszej publikacji jest próba określenia roli i znaczenia aktywności fizycznej wśród subpopulacji w okresie inwolucji. W społeczeństwie XXI wieku proces starzenia się i starości jest nieunikniony oraz nieodwracalny. Z danych literaturowych wynika, że współczesne społeczeństwo nacechowane jest licznymi zmianami. Jednym z wymiarów tej konwersji jest wydłużanie się przeciętnego wieku życia. Z estymacji Głównego Urzędu Statystycznego wynika, że w 2050 r. aż jedna trzecia naszego społeczeństwa będzie w wieku $65+$. W związku z powyższym należy właściwie przygotować społeczeństwo do tej demograficznej zmiany. Jednym z istotnych czynników w tej strategii powinno być wychowanie społeczeństwa ku starości oraz w starości. Poza tym instytucje i organizacje zajmujące się szeroko rozumianą kulturą fizyczną powinny podejmować działania edukacyjne w celu uświadamiania społeczeństwu pozytywnych skutków wynikających z czynnego uczestnictwa w różnych formach aktywności fizycznej. Partycypacja różnych grup społecznych, w tym i osób starszych, jak wynika z literatury przedmiotu, stanowi zarówno źródło zdrowego starzenia się, jak i skuteczny środek dla nasilającego się zjawiska, jakim jest hipokineza.
\end{abstract}

SŁOWA KLUCZOWE: starość, proces starzenia się, aktywność fizyczna, zdrowy styl życia.

\section{Wprowadzenie}

„(...) Szukając tematu na badanie, warto zająć się tym, co nas fascynuje - zaangażowanie w problem zwiększa znacząco szanse, że projekt zostanie z sukcesem ukończony" [1]. Powyższa konstatacja stała się myślą przewodnią dla autorów niniejszej publikacji.

Dokonując analizy literatury dotyczącej zmian zachodzących w polskim społeczeństwie, przede wszystkim zmian w obszarze demograficznym, widać, że uwaga badaczy zwrócona jest przede wszystkim na zjawisko starzenia się i starości, które dotyka społeczeństw post-

\begin{abstract}
The purpose of this publication is an attempt to define the role and importance of physical activity among subpopulations in the period of involution. In the society of the 21 st century the process of aging and old age is inevitable and irreversible. From literature data it follows that the modern society founded numerous changes. One of the dimensions of this transformation is the increase in the average age of life. The assessment of the Central Statistical Office shows that in 2050 up to $1 / 3$ of our population will be 65 . In connection with the foregoing, the public should be properly prepared for this demographic change. One of the important factors in this strategy should be the education of the society to the old age and in the old age. In addition, institutions and organizations engaged in all sorts of physical fitness must take educational activities to educate the public of the positive effects deriving from the active participation in various forms of physical activity. The participation of various social groups, including older people, as can be seen from the literature of the subject is the source of healthy aging and is an effective tool for the growing phenomenon, which is hypokinesis.
\end{abstract}

KEYWORDS: old age, aging process, physical activity, healthy lifestyle.

industrialnych. Szybki rozwój wiedzy, medycyny czy komunikacji to tylko nieliczne składniki będące swoistymi implikatorami konwersji współczesnego społeczeństwa tak na świecie, jak i w Polsce. Zmiany te obejmują m.in. wydłużanie przeciętnego wieku.

Sztandarowa publikacja zatytułowana Europejski Raport Zdrowia 2012: Droga do osiągnięcia dobrostanu przygotowana przez Europejskie Biuro Regionalne WHO (raporty takie ukazują się co 3 lata) jest potwierdzeniem powyższej tezy twórców niniejszej publikacji. Z raportu wynika, że wydłuża się wiek przeciętnego mieszkańca Europy. Jak zauważają autorzy, spowodo- 
wane jest to „zmniejszeniem częstotliwości przyczyn pewnych zgonów oraz poprawą w zakresie występowania czynników ryzyka” i „warunków życiowych i społeczno-ekonomicznych" [2].

Według estymacji Narodowego Programu Zdrowia 2007-2015 wynika, że w ostatnim 10-leciu wzrosła średnia długość trwania życia (dla kobiet do 79,4 roku, dla mężczyzn do 70,81 roku), a umieralność niemowląt została zredukowana do wskaźnika 6,4 na 1000 żywych urodzeń [3].

W jednej z prac E. Kozdroń także zauważa powyższą tendencję. Autorka w publikacji Aktywność rekreacyjna w procesie pomyślnego starzenia się konstatuje, że „Polska, tak jak większość europejskich krajów, jest krajem »siwiejącym « - przybywa w naszym społeczeństwie osób powyżej 60. roku życia" [4].

\section{Podstawowe pojęcia}

Analizując zjawisko aktywności fizycznej, autorzy dokonają w tym miejscu artykułu ustaleń terminologicznych i typologicznych, odnoszących się do starości i starzenia się, aktywności fizycznej, wykorzystując typowy zakres pojęciowy pojawiający się w literaturze przedmiotu.

Starość jest zjawiskiem biologicznym - elementem cyklu życia ludzkiego. T.B. Kirkwood w jednej ze swych prac stwierdza, że starzenie się jest procesem postępującego upośledzenia funkcji życiowych organizmu oraz utraty zdolności adaptacyjnych do zmian środowiskowych wraz ze zwiększającym się prawdopodobieństwem zgonu [5]. Starzenie się, zgodnie z przyjętym w literaturze psychogerontologicznej określeniem, oznacza pewien proces i ma charakter dynamiczny, podczas gdy starość jako stan ma charakter statyczny [6].

Poddając analizie teoretycznej pojęcie aktywności fizycznej, należy na wstępie zauważyć, że jest to najważniejszy po odżywianiu czynnik determinujący zdrowie. W doskonaleniu autosystemów regulacyjnych organizmu stawiana jest bezsprzecznie na pierwszym miejscu. Jest ona czynnikiem modelującym w sposób najbardziej korzystny stan morfologiczny i funkcjonalny organizmu, a także istotnym czynnikiem kształtującym cechy psychiczne. W. Osiński dodaje, że aktywność fizyczna ,podejmowana systematycznie w istotnym stopniu wpływa na zachowanie, a także umacnianie zdrowia człowieka" [7].

Aktywność fizyczną definiuje się jako „...każdy ruch ciała związany z kurczeniem się mięśni, który zwiększa wydatek energetyczny powyżej poziomu spoczynkowego" [8]. Tak szeroko rozumiana aktywność fizyczna odnosi się do wszelkich zajęć związanych z wysiłkiem towarzyszącym różnym formom kultury fizycznej, np.: zajęć sportowych i rekreacyjnych czy też uprawiania turystyki, podejmowanych zajęć w czasie wolnym, pod- czas zabawy, jak również do codziennych zajęć, takich jak chodzenie, prace domowe oraz praca zawodowa związana z wysiłkiem fizycznym.

Przechodząc do analizy pojęcia zdrowego (prozdrowotnego) stylu życia, należy zaznaczyć, że termin ten odnosi się zazwyczaj do uczestnictwa w różnorodnych formach aktywności fizycznej, a literatura przedmioty definiuje to zachowanie jako: „...wzór świadomych zachowań związanych ze zdrowiem, będący efektem wyborów dokonywanych przez ludzi na podstawie dostępnych, determinowanych ich sytuacją życiową alternatyw; nie tylko wzór zachowań związany ze zdrowiem, ale także wartości i postawy reprezentowane przez ludzi w odpowiedzi na warunki ich społecznego, kulturowego i ekonomicznego środowiska" [9].

\section{Analiza literatury}

Złożoność oraz wielowymiarowość tej tematyki sprawiają, że diagnozowanie tego procesu jest zadaniem niełatwym i wymaga podejścia interdyscyplinarnego w wymiarze zarówno teoretycznym, jak i praktycznym.

Problematyka osób starszych z tego m.in. powodu stała się przedmiotem badań interdyscyplinarnych.

Istniejące estymacje demograficzne przygotowane przez GUS wskazują na wzrost liczby osób w wieku 60+ w polskim społeczeństwie. Rycina 1 przedstawia zestawienie danych procentowych dotyczących odsetka osób w wieku 65+ od 1980 r.

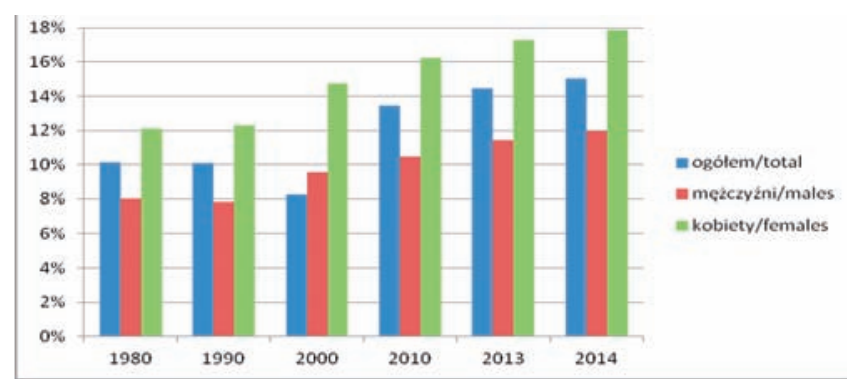

Rycina 1. Liczba osób w wieku 65+ w Polsce (dane w \%) Figure 1. Number of people aged $65+$ in Poland (data in \%)

Źródło: Odsetki osób w wieku 65+ w Polsce. Rocznik demograficzny 2014. Warszawa: Główny Urząd Statystyczny

Source: Percentage of people aged 65+ in Poland. Demographic year-book 2014. Warsaw: Central Statistical Office

Prognozy demograficzne wskazują także, że proces starzenia się społeczeństw tak na świecie, jak i w Polsce jest nieunikniony oraz nieodwracalny. Dane liczbowe sięgające do 2050 r. wskazują, że odsetek osób w wieku 65+ będzie stale wzrastał (Rycina 2). Z poniższej tabeli wynika, że w połowie XXI wieku aż jedna trzecia naszego społeczeństwa będzie w wieku 65+. 


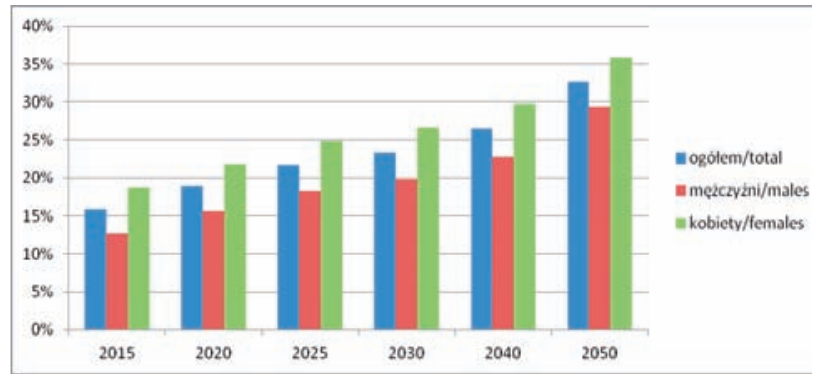

Rycina 2. Liczba Polaków w wieku 65+ (dane w \%) Figure 2. Number of Polish people aged 65+ (data in \%)

Źródło: Prognoza demograficzna dotycząca liczby kobiet i mężczyzn w wieku 65+ w Polsce. Rocznik demograficzny 2014. Warszawa: Główny Urząd Statystyczny

Source: Demographic prognosis on the numer of women and men aged 65+ in Poland. Demographic year-book 2014. Warsaw: Central Statistical Office

Z kolei przyjmując założenie WHO [10], które wyróżnia trzy etapy życia: 60-74 lata: „młoda” starość (III wiek, young old), 75-89 lat: „dojrzała” starość (IV wiek, oldest old), 90 lat i więcej: długowieczność (oldest old, long life), należy przyjąć, że po 2025 r. drastycznie wzrośnie odsetek 80-latków i starszych z uwagi na fakt, że ten wiek - w kolejnych latach - osiągną osoby urodzone w 1945 r. i później, a więc „pochodzące” z powojennego boomu urodzeń, zaś echo tego wyżu zasili grupę osób w wieku 65 lat i więcej. W 2040 r. osoby ponad 80 -letnie będą stanowiły aż $36 \%$ zbiorowości osób starszych - 65 lat i więcej. W końcu prognozowanego okresu proporcje nieco ulegną zmianie i odsetek osób 80+ w ogólnej populacji osób starszych (65 lat i więcej) zmniejszy się do 32\% (Rycina 3).

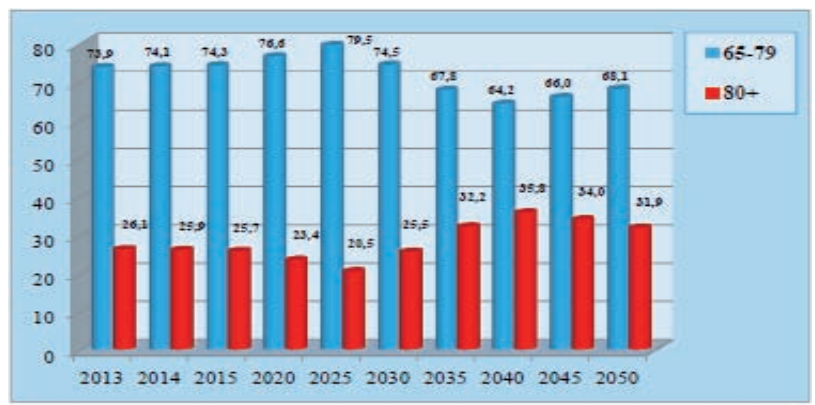

Rycina 3. Struktura populacji osób starszych (osoby w wieku 65 lat i więcej $=100 \%$ )

Figure 3. Population structure of elder people (people aged 65 and more $=100 \%$ )

Źródło: Prognoza ludności na lata 2014-2050. Studia Analiz Statystycznych. Warszawa: GUS, Departament Badań Demograficznych i Rynku Pracy; 2014. 137

Source: Demographic prognosis for 2014-2050. Statistical Analyses Studies. Warsaw: Central Statistical Office, Department of Demographic Research and Labour Market; 2014. 137
Należy przeciwdziałać niekorzystnym (destruktywnym) zmianom w okresie inwolucji, która - jak wynika z przedstawionych estymacji - jest procesem nieuniknionym i przybierającym na sile.

Trzeba zatem właściwie przygotować się do starości zarówno własnej, jak i cudzej. Ogromną rolę w tej kwestii odgrywa wychowanie społeczeństwa ku starości oraz w starości.

Istotnym czynnikiem w tej strategii wychowawczej są podejmowane działania edukacyjne w celu uświadamiania społeczeństwu, a w szczególności subpopulacji, jaką stanowią osoby starsze, że czynne uczestnictwo w różnych formach aktywności fizycznej przyniesie pozytywne rezultaty. Popularyzowanie tej formy aktywności człowieka oraz zachęcanie osób starszych do uczestnictwa w szeroko rozumianej kulturze fizycznej stanowi spiritus movens zdrowego starzenia się (ang. successful ageing) w wymiarze fizycznym, psychicznym oraz społecznym. Już Hipokrates - starożytny lekarz z Kos - zalecał ruch jako środek działający pozytywnie na cały organizm człowieka [11], a w wieku XVI W. Oczko - nadworny lekarz królów polskich Stefana Batorego oraz Zygmunta III Wazy - stwierdził, że ruch jest w stanie zastąpić każdy lek, ale wszystkie leki razem wzięte nie zastąpią ruchu. Z kolei raport Global Health Risk WHO z 2009 r. wskazuje, że wśród 24 czynników wpływających na zwiększenie ryzyka śmiertelności na świecie brak aktywności ruchowej jest trzecim czynnikiem ryzyka odpowiedzialnym za ogólną śmiertelność - 6\% (wysokie ciśnienie tętnicze odpowiedzialne jest za 13\% zgonów na świecie, a palenie tytoniu - 9\%) [12].

Przez liczne instytucje i organizacje społeczne realizowane są zadania zmierzające do popularyzacji tego modelu (M. Demel 1980, W. Siwiński 1992, R. Winiarski 1989, T. Wolańska 1988, A. Gniazdowski 1990, B. Woynarowska 1993, W. Siwiński 2000, Z. Żukowska, R. Żukowski 2003, J. Nowocień 2013).

Do takich instytucji i organizacji realizujących od wielu lat zadania w zakresie działań popularyzujących i aktywizujących m.in. seniorów do partycypowania w różnych formach kultury fizycznej zaliczyć należy m.in. WHO, która organizuje od 2003 r. imprezy mające na celu promowanie korzyści wynikających z uczestnictwa w różnych formach aktywności fizycznej. Imprezy zwane Dniem Aktywności na rzecz Zdrowia (ang. Move for Healthy Day) odbywają się corocznie w połowie maja. Warto przywołać tu również Europejskie Stowarzyszenie Promocji Aktywności Ruchowej 50+ (ESPAR 50+), którego misją jest budowanie i utrwalanie prozdrowotnych postaw osób dorosłych, czy też Towarzystwo Krzewienia Kultury Fizycznej (TKKF), które m.in. promuje zdrowy styl życia. 
Poza tym do polskich instytucji popularyzujących aktywność fizyczną zaliczyć należy m.in.:

- Ministerstwo Sportu i Turystyki,

- Polską Organizację Turystyczną,

- Regionalną Organizację Turystyczną,

- Lokalną Organizację Turystyczną,

- Polską Izbę Turystyki,

- Polską Agencję Rozwoju Turystyki,

- Polskie Towarzystwo Turystyczno-Krajoznawcze,

- Polskie Stowarzyszenie Turystyki.

Z literatury przedmiotu wynika, że obciążenie organizmu wysiłkiem określane jest w różny sposób: może to być wydatek energetyczny (kcal) potrzebny do wykonania wysiłku; zapotrzebowanie na tlen podczas obciążenia bezwzględnego wyrażonego w MET (gdzie 1 MET - ekwiwalent metaboliczny - odpowiada zapotrzebowaniu na tlen w spoczynku w pozycji siedzącej i wynosi $3,5 \mathrm{ml} / \mathrm{kg} / \mathrm{min}$ ); lub miara względnej intensywności wysiłku wyrażona odsetkiem maksymalnej częstości serca HRm (ang. heart rate) lub procentem maksymalnego pochłaniania tlenu $\mathrm{VO}_{2} \max$ (ang. $\mathrm{V}$ volumne, $\mathrm{O}_{2}$-oxygen). Do tego celu można wykorzystać także subiektywne skale odczucia ciężkości wysiłku, spośród których najbardziej znana jest skala Borga, lub będące w codziennym użyciu krokomierze [13-15].

Za niedostateczną uważa się aktywność fizyczną o intensywności poniżej 4-5 MET i/lub wydatku energetycznym mniejszym niż 500 kcal/tydzień [16]. Według J.J. Varo i wsp. za niedostateczną należy przyjąć aktywność fizyczną, przy której wydatek energetyczny wynosi mniej niż 10\% całkowitego dobowego wydatku energetycznego [17], z kolei A.C. Leon uważa, że deficyt w ww. zakresie występuje wtedy, gdy jest krótszy niż $25 \mathrm{~min} /$ dzień [18].

Przyjmując powyższe kryteria, należy stwierdzić, że 40-60\% populacji UE prowadzi siedzący tryb życia (Eurobarometr - marzec 2010). W Polsce w zależności od wieku dotyczy to $50-70 \%$ populacji [19]. Jeżeli przeanalizujemy aktywność fizyczną osób starszych, zauważyć należy, że poziom tej aktywności jest niezadowalający. W Polsce styl życia osób starszych można określić raczej jako bierny. Około 80\% ludzi starszych (w okresie wczesnej starości, czyli do 75. roku życia) jest mobilnych ruchowo [20], ponad $50 \%$ badanych deklaruje potrzebę ruchu, a do podejmowania aktywności fizycznej raz w tygodniu przyznaje się 12\% Polaków 60+ [21].

Barierami aktywności fizycznej są najczęściej czynniki zdrowotne, psychologiczne oraz społeczno-kulturowe, do których należą m.in. negatywne uprzedzenia oraz stereotypy.

Mimo tych barier dla coraz większej grupy polskich seniorów dysponujących dużą ilością wolnego czasu kultura fizyczna stanowi pożądany model zdrowego sty- lu życia, a tym samym przyczynia się on do łagodzenia procesu inwolucji, tj. do pozytywnego starzenia się.

J. Nowocień konstatuje, że odpowiednio dobrana, zaplanowana i podejmowana aktywność fizyczna jest najlepszym lekarstwem w tym nieuchronnym procesie [22].

\section{Podsumowanie}

Dokonując krótkiego podsumowania, należy skonstatować, że aktywność fizyczna jest swoistym fenomenem człowieka żyjącego w erze "globalnych przepływów kulturowych" (A. Appadurai). Istotą tego fenomenu jest fakt, że stanowi spiritus movens zdrowego starzenia się (ang. successful ageing) w wymiarze fizycznym, psychicznym oraz społecznym.

Instytucje i organizacje zajmujące się krzewieniem kultury fizycznej powinny stale podejmować działania o charakterze toposu w celu popularyzacji zdrowego stylu życia oraz aktywizacji społeczeństwa, w tym i osób starszych, zachęcając do systematycznych działań rekreacyjnych, które stanowią „odtrutkę" przeciwko nieuchronnemu procesowi inwolucji. Taka edukacja zdrowotna ma na celu przeformatowanie postaw społecznych w zakresie wyborów dotyczących aktywnych zachowań podejmowanych w wolnym czasie w taki sposób, by stały się one powszechnie akceptowanym priorytetem oraz swoistym signum temporis dzisiejszego społeczeństwa.

\section{Piśmiennictwo}

1. Stasik A, Gendźwiłł A. Projektowanie badania jakościowego. W: Jemielniak D (red.). Badania jakościowe. Podejścia i teorie. Tom I. Warszawa: PWN; 2012. 3.

2. WHO. Europejski Raport Zdrowia 2012: Droga do osiągnięcia dobrostanu, www.spif.pl/wp-content/uploads/2015/.../Europejski-Raport-Zdrowia-2012 (data dostępu: 20.02.2016).

3. Kuszewski K, Goryński P, Wojtyniak B, Halik R (red.). Narodowy Program Zdrowia 2007-2015. Załącznik do Uchwały Nr 90/2007 Rady Ministrów z dnia 15 maja 2007 r. Warszawa; 2007.9

4. Kozdroń E. Aktywność rekreacyjna w procesie pomyślnego starzenia się. Zeszyty Naukowe WSKFiT. 2014; 9: 75-84.

5. Kirkwood TB. Human Senescence. BioEssay. 1996; 18 (12).

6. Porzych K, Kędziora-Kornatowska K, Porzych M. Psychologiczne aspekty starzenia się i starości. Gerontol Pol. 2004; $12(4)$.

7. Bojar I, Wojtyła K, Owoc A. Aktywność fizyczna uczniów szkół podstawowych powiatu miasta Kalisz i powiatu kaliskiego. Med Ogólna. 2010; 16 (45) 1: 33.

8. EU Working Group. Sport and Health (2008) EU Physical Activity Guidelines, http://ec.europa.eu/sport/what-we do/ doc/health/pa_guidelines_4th_consolidated_draft_en.pdf (data dostępu: 08.03.2016).

9. Ostrowska A. Styl życia a zdrowie: z zagadnień promocji zdrowia. Warszawa: Wyd. Instytutu Filozofii i Socjologii PAN; 1999. 27.

10. Prognoza ludności na lata 2014-2050. Studia Analiz Statystycznych. Warszawa: GUS, Departament Badań Demograficznych i Rynku Pracy; 2014. 135. 
11. Karwat ID, Jędrych M. Skawiński D, Piecewicz-Szczęsna H, Sobieszczański J, Żukow W, Fronczek M, Borzęcki P. Zdrowie i niepełnosprawność - problemy w definiowaniu. Cz. 9. Cechy wykorzystywane w ocenie stanu zdrowia. J Health Sci. 2012; 2 (5); 87-100.

12. WHO. Global health risks: mortality and burden of disease attributable to selected major risks. Geneva: WHO Press; 2009.

13. Kozłowski S, Nazar K. Wprowadzenie do fizjologii klinicznej. Wyd. II. Warszawa: PZWL; 1995.

14. Koradecka $D$ (red.). Bezpieczestwo pracy i ergonomia. Warszawa: CIOP; 1997.

15. Koradecka D, Bugajska J. Ocena wielkości obciążania pracą fizyczną na stanowiskach roboczych. Warszawa: CIOP; 1998.

16. Drygas W, Piotrowicz R, Jegier A, Kopeć G, Podolec P. Aktywność fizyczna u osób zdrowych. W: Podolec $\mathrm{P}$ (red.). Podręcznik Polskiego Forum Profilaktyki. Tom II. Kraków: Medycyna Praktyczna; 2010. 437-442.

17. Varo JJ, Martinez-Gonzalez MA, Kearney J, Gibney M, Martinez JA. Distribution and determinants of sedentary lifestyles in the European Union. Int J Epidemiol. 2003; 32: 138.

18. Leon AC, Rodriguez-Perez M, Rodriguez-Benjumeda L, Ania-Lafuente B, Brito-Diaz B, Muros de Fuentes M, Almeida-Gonzales D, Batista-Medina M, Aguirre-Aime A. Sedentary lifestyle: Physical actiyity duration yersus percentage of energy expenditure. Rey Esp Cardiol. 2007; 60: 244.

19. Wyniki badań GUS - Uczestnictwo Polaków w sporcie i rekreacji ruchowej w 2008 r. Warszawa: GUS; 2009.
20. Gębska-Kuczerowska A. Uwarunkowania mobilności osób w wieku 65 lat i więcej. W: Charzewski J (red.). Problemy starzenia. Warszawa: Wyd. AWF; 2001. 111-113.

21. Wyniki badań GUS - Uczestnictwo Polaków w sporcie i rekreacji ruchowej w 2012 r. Warszawa: GUS; 2013.

22. Nowocień J. Studium o pedagogice kultury fizycznej. Warszawa: Wyd. AWF; 2013. 67.

Artykuł przyjęty do redakcji: 30.04 .2015

Artykuł przyjęty do publikacji: 09.07.2015

Źródło finansowania: Praca nie jest finansowana z żadnego źródła. Konflikt interesów: Autorzy deklarują brak konfliktu interesów.

Adres do korespondencji:

Grzegorz Konieczny

ul. Królowej Jadwigi 27/39

61-871 Poznań

tel.: 618355418

e-mail: gkonieczny@awf.poznan.pl

Akademia Wychowania Fizycznego im. Eugeniusza Piaseckiego

w Poznaniu 